\title{
Characteristics of color and iron oxides of clay fraction in Archeological Dark Earth in Apuí region, southern Amazonas
}

\author{
Renato Eleoterio de Aquino a , José Marques Jr. a , Milton César Costa Campos ${ }^{\text {b,* }}$, Ivanildo Amorim de Oliveira a , \\ Angélica Santos Rabelo de Souza Bahia ${ }^{a}$, Luis Antônio Coutrim dos Santos ${ }^{\mathrm{c}}$ \\ a Agrarian and Veterinarian Faculty, São Paulo State University, 14883-292 Jaboticabal, SP, Brazil \\ b Institute of Education, Agriculture and Environment, Universidade Federal do Amazonas, 69800-000 Humaitá, AM, Brazil \\ c Department of Soil, Center of Rural Sciences, Universidade Federal de Santa Maria, 97105-900 Santa Maria, RS, Brazil
}

\section{A R T I C L E I N F O}

\section{Article history:}

Received 9 February 2015

Received in revised form 20 June 2015

Accepted 12 July 2015

Available online 25 August 2015

\section{Keywords:}

Anthropogenic horizon

Anthropogenic soil

Diffuse reflectance spectra

Hematite

Goethite

\begin{abstract}
A B S T R A C T
One of the marks left by prehistoric man in the Amazonas landscape are the dark-colored soil stains, Archeological Dark Earth (ADE), which are rich in organic matter, phosphorus and calcium. The color in this soil is presented as an attribute of difficult interpretation on the horizon, and the studies towards a better identification are important. In this sense, the objective of this study was to characterize the color and iron oxides of the ADE clay fraction in Apuí region in southern Amazonas. Six trenches were opened, where these profiles were characterized morphologically, and also samples were collected per horizon for later performance of grain size analysis, flocculation, water clay dispersion and chemicals ( $\mathrm{pH}$ in water and potassium chloride, calcium, magnesium, potassium, phosphorus, potential acidity, f, organic carbon and organic matter) and mineralogical analyses. The data were submitted to principal component analysis. Similar behavior in the studied profiles was found both in physical and chemical attributes. It was concluded that the hematite and goethite, determined by $\mathrm{x}$-ray diffraction and diffuse reflectance spectroscopy, besides not presenting significant variations between the studied soils, present similar characteristics to non-anthropogenic Brazilian soils. The color measured by diffuse reflectance spectroscopy proved efficient to indicate variations among the ADEs, proving to be an innovative technique, efficient and promising for indirect quantification of soil characteristics in a simple and low cost manner. The results show that iron oxides demonstrate be sensitive indicators of pedoenvironmental conditions and pedogenic processes of Archeological Dark Earth.
\end{abstract}

C 2015 Elsevier B.V. All rights reserved.

\section{Contents}

1. Introduction $\ldots .35$

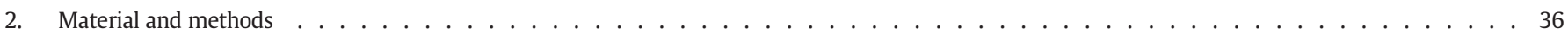

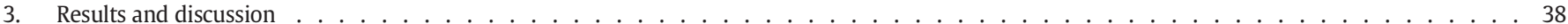

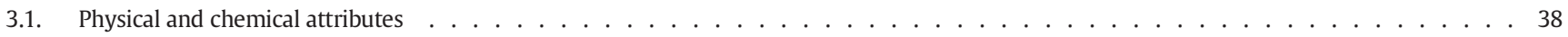

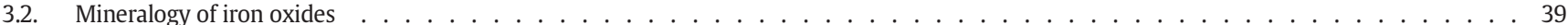

3.3. Color measurement and determination of hematite and goethite by XRD and DRS . . . . . . . . . . . . . . . . . . . . . . . 42

3.4. Multivariate analysis $-\mathrm{PCA} \ldots \ldots \ldots \ldots \ldots$

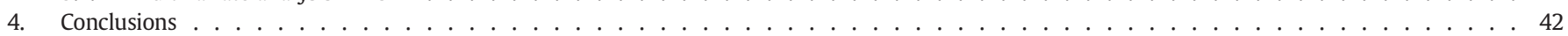

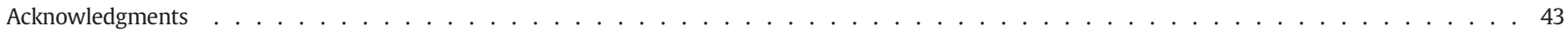

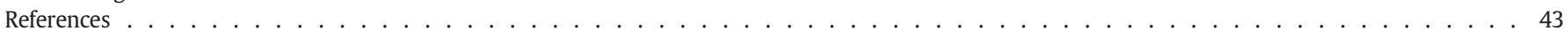

* Corresponding author.

E-mail addresses: aquino.rea@gmail.com (R.E. Aquino), marques@fcav.unesp.br (J. Marques), mcesarsolos@gmail.com (M.C.C.Campos), ivanildoufam@gmail.com (I.A. Oliveira), angelicasantosrabelo@yahoo.com.br (A.S.R.S. Bahia), santoslac@gmail.com (L.A.C. Santos).

\section{Introduction}

Soils in Amazonas, known as Archeological Dark Earth (ADE), contrast with no anthropogenic soils of the Amazonas region, mainly due to its natural fertility difference which is characterized by the wide 
availability of nutrients such as calcium (Ca), magnesium (Mg), zinc (Zn) and manganese (Mn) (Kern and Kämpf, 1989; Cunha et al., 2009) (Kern and Kämpf, 1989; Kern et al., 2003; Cunha et al., 2009), high organic matter (OM), high $\mathrm{OM}$, intense biological activity, $\mathrm{pH}$ in water around 5.2 to 6.4 ; available phosphorus $(\mathrm{P})$ in general above $250 \mathrm{mg} \mathrm{dm}^{-3}, \mathrm{Zn}$ and $\mathrm{Mn}$ above 200 and $450 \mathrm{mg} \mathrm{kg}^{-1}$, respectively (Lima et al., 2002). The anthropogenic horizons of ADEs are well drained, texture ranging from sandy to heavy clay and the presence of anthropogenic horizon A between 0.30 and $0.60 \mathrm{~m}$ depth (Campos et al., 2012; Santos et al., 2013). In terms of geographical distribution, German (2003) stated that the soils of the ADEs are distributed in the form of discontinuous spots throughout the Amazon. They are located in areas near watercourses (Centro de Pesquisa de Recursos Minerais - CPRM, 2010), in marginal elevations, upland and lowland areas (Teixeira and Martins, 2003; Macedo and Teixeira, 2009).

Studies in ADE soils occur mainly for fertility purposes and on a smaller scale for studies of its genesis, its physical (Moreira, 2006; Kim et al., 2007; Santos et al., 2013) and microbiological attributes, where Navarrete et al. (2010) claim that the soil microbial community can be strongly influenced with the support of the black carbon present in ADEs. Researches oriented to the mineralogy of the ADEs is still incipient, specifically for clay fraction oxides that are even scarcer. However, studies concerning the ADE iron oxides are required, taking into account the importance of oxides in tropical and subtropical soils, once they are characterized by being sensitive indicators of pedo-environmental conditions and pedogenic processes (Schwertmann and Taylor, 1989).

Soil color is a property that is indicative of iron oxide presence or absence, which varies according to the mineral type or proportions between them, as well as their distribution over the soil, having an outstanding importance in the soil classification system of Brazil (Resende et al., 2007). However, this determination, used worldwide by pedologists, is based on visual perception, that is, subjective, and according to Campos and Demattê (2004), differences in color perception can result in classification errors.

Color analysis with measuring instruments, such as the diffuse reflectance spectroscopy (DRS), results in greater precision, given the controlled and not subjective conditions. Several authors (Torrent and Barron, 1993; Barrón et al., 2000; Viscarra Rossel and Webster, 2011; Bahia et al., 2014) have demonstrated the potential use of this technique. The advantages of DRS over traditional methods are rapidity, cost savings, no use of reagents and being a non-destructive method (Brown et al., 2006; Viscarra Rossel et al., 2006).

Therefore, the detailed characterization of DAEs can contribute to understanding its genesis and behavior in specific environments of the Amazon, allowing the establishment of hypotheses in the reproduction of artifacts of their main qualities. Moreover, the hypothesis of this study is that soil color characterization can be an important tool to estimate soil attributes, especially iron oxides. Given the above, the objective of this study was to characterize soil color and iron oxides of clay fraction in Dark Archeological Earth within the region of Apuí, in the state of Amazonas.

\section{Material and methods}

The study area is located in the southern Amazonas distributed in the Apuí region (Fig. 1). The climate is hot and humid with little pronounced dry season, "Am" type by the Köppen classification (1948). The average annual temperature varies between $25^{\circ} \mathrm{C}$ and $27{ }^{\circ} \mathrm{C}$, relative humidity of $85 \%$, and with rainfall above $2200 \mathrm{~mm}$ per year (Centro de Pesquisa de Recursos Minerais - CPRM, 2001).

The geology of the Apuí region involves the geological domain formed by older rocks (Proterozoic and Paleozoic), inserted within Central Brazil Shield cratonic area with predominantly crystalline rocks (granites and gneisses, volcanic coverage and metasedimentary rocks) (Secretaria de estado do meio ambiente e desenvolvimento sustentável - SDS, 2004).
Representative locations of the DAEs, as shown in Fig. 1 and Table 1, have an average of 10-year non-intensive agricultural exploration and use. In these places, trenches were opened and the soil profiles were characterized morphologically and collected by horizon according to Santos et al. (2005). Physical, chemical and mineralogical analyses were performed in the samples. Then, the soils were classified according to criteria established by the Brazilian Society of Soil Science and Soil Taxonomy (Empresa Brasileira de Pesquisa Agropecuária - EMBRAPA, 2013; Soil Survey Staff, 1999).

The particle size analyses were performed using a $\mathrm{NaOH} 0.1 \mathrm{~mol} \mathrm{~L}^{-1}$ solution as chemical dispersant and mechanical stirring in high-speed apparatus for $15 \mathrm{~min}$. The clay fraction was separated by sedimentation using a pipette for its removal, the coarse and fine sand by sieving and the silt was calculated by difference. The water dispersed clay was determined and the degree of flocculation was calculated (Empresa Brasileira de Pesquisa Agropecuária - EMBRAPA, 1997).

The $\mathrm{pH}$ was determined potentiometrically using a 1:2.5 ratio of soil in water and $\mathrm{KCl}$ (Empresa Brasileira de Pesquisa Agropecuária EMBRAPA, 1997). Contents of Ca, Mg, exchangeable K, available P, and potential acidity $(\mathrm{H}+\mathrm{Al})$ were extracted by ion-exchange resin method (van Raij et al., 1987). The total organic carbon (TOC) was determined by the Walkley-Black method modified by Yeomans and Bremner (1988). The OM was estimated based on organic carbon. Using results of chemical analysis, the sum of bases (SB), the cation exchange capacity (CEC) and the base saturation (V\%) were calculated.

To obtain the diffuse reflectance spectra (DRS), evaluations were made with the laboratory Perkin-Elmer Lambda 950 UV/Vis/NIR sensor (Perkin Elmer, United Kingdom), equipped with $80 \mathrm{~mm}$ integrating sphere. Approximately $0.5 \mathrm{~g}$ of fine air-dried soil (FADS) was ground in an agate mortar until constant color was obtained. The content was placed into a sample holder with a cylindrical space of $16 \mathrm{~mm}$ in diameter. The reflectance values were determined every $0.5 \mathrm{~nm}$ with an integration time of $0.2 \mathrm{~s}$, performing a scanning at the range of $380-780 \mathrm{~nm}$. After obtaining the diffuse reflectance spectra of the soil samples, the tristimulus values XYZ defined by the International Comisión de L'Eclairage were determined. From the XYZ coordinates, the Munsell Values (hue, value and chroma) and RGB (used for digital representation of color) were deduced using the Munsell Conversion software version 6.4, according to Barrón et al. (2000).

For the $\mathrm{x}$-ray analysis diffraction (XRD), clay was separated from the soil sample by centrifugation method. Minerals from the clay fraction hematite (Hm) and goethite (Gt) were characterized by XRD in blades made with powdered material. The characterization of $\mathrm{Hm}$ and $\mathrm{Gt}$ occurred after treating clay fraction with $\mathrm{NaOH} 5 \mathrm{~mol} \mathrm{~L}^{-1}$ ( 1 g clay per $100 \mathrm{ml}$ solution) for the concentration thereof, according to Norrish and Taylor (1961) method and modified by Kämpf and Schwertmann (1982). The ratio Gt / (Gt $+\mathrm{Hm})$ was obtained after calculation of reflection areas of $\mathrm{Hm}$ (012) and Gt (110), in the diffractogram reflections; and in this case, the Gt (110) peak area was multiplied by 0.35 due to $35 \%$ of $\mathrm{Hm}$ (012) intensity (Kämpf and Schwertmann, 1998). The mean crystal diameter (MCD) was calculated from the width at half-maximum height (WHH) of the Hm (110 and 012) and Gt (110 and 111) reflections using the Scherrer equation (Klug and Alexande, 1974).

The diffractometer used was the Mini-Flex Rigaku II, using copper cathode with nickel filter and $\mathrm{k} \alpha$ radiation $(20 \mathrm{~mA}, 30 \mathrm{kV})$. The scan speed was of $1^{\circ} 2 \theta$ per minute with amplitude 23 to $49^{\circ} 2 \theta$ for the $\mathrm{Hm}$ and Gt characterization.

Procedures suggested by Schulze (1984) were used to calculate isomorphic substitution $\left(\mathrm{mol} \mathrm{mol}^{-1}\right.$ ) of iron by aluminum in $\mathrm{Gt}$, to which is proposed the following equation:

$\operatorname{molAl} \%=1730-572 \cdot \mathrm{c}$

where, $c=1 /\left(1 / d_{111}^{2}-1 / d_{110}^{2}\right)^{1 / 2}$. 


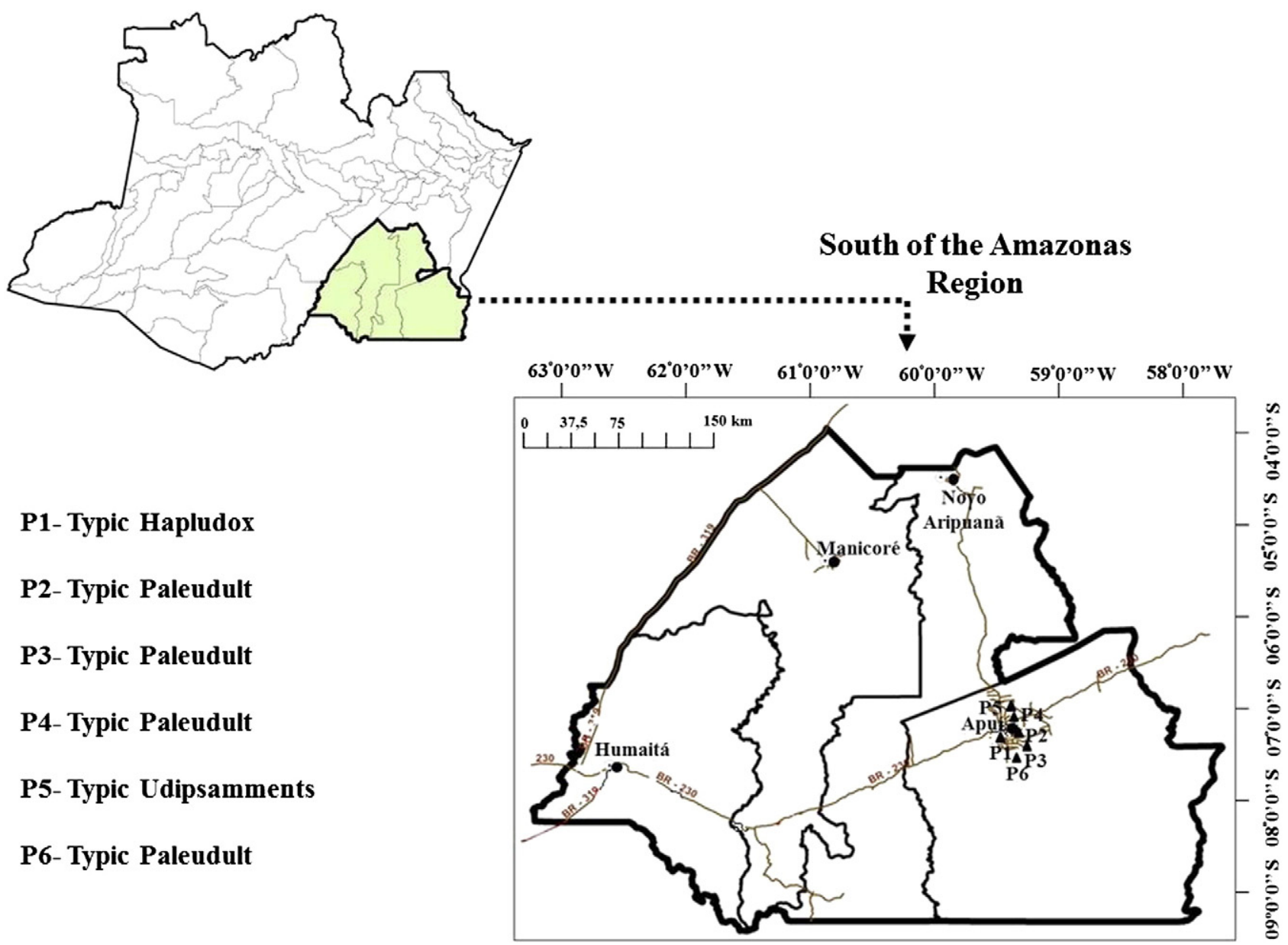

Fig. 1. Map showing location of soil profiles in Apuí region, southern of Amazonas state, Brazil.

As for the calculation of isomorphous substitution content ( $\mathrm{mol} \mathrm{mol}{ }^{-1}$ ) of iron by aluminum in $\mathrm{Hm}$, the equation proposed by Schwertmann et al. (1979) was used:

$\operatorname{molAl} \%=3098.8-615.12 \cdot \mathrm{a}_{0}$

where, $\mathrm{a}_{0}=2 \mathrm{~d}_{110}$.

The crystalline iron content was multiplied by the ratio Gt / $(\mathrm{Gt}+\mathrm{Hm})$ and by 1.59 to obtain estimates of Gt content. Yet for hematite, it was multiplied by 1.43 , and then subtracting from this value the

Table 1

Identification of profiles, coordinates, location, occupation, position.

\begin{tabular}{|c|c|c|c|c|}
\hline Profile & Coordinate & Location & Occupation & Position \\
\hline 1 & $\begin{array}{l}\mathrm{S} 07^{\circ} 6^{\prime} 32,8^{\prime \prime} \\
\text { W } 59^{\circ} 51^{\prime} 6,9^{\prime \prime}\end{array}$ & ${ }^{1}$ Vic. Mariano Km 4 & Corn & Top down \\
\hline 2 & $\begin{array}{l}\text { S } 07^{\circ} 6^{\prime} 54,9^{\prime \prime} \\
\text { W } 059^{\circ} 52^{\prime} 22,1^{\prime \prime}\end{array}$ & Vic. Sulino Km 11 & Orchard & Top \\
\hline 3 & $\begin{array}{l}\text { S } 07^{\circ} 7^{\prime} 9,1^{\prime \prime} \\
\text { W } 59^{\circ} 46^{\prime} 1,1^{\prime \prime}\end{array}$ & BR $230 \mathrm{Km} 17$ & Pasture & Top \\
\hline 4 & $\begin{array}{l}\mathrm{S} 07^{\circ} 9^{\prime} 5,7^{\prime \prime} \\
\mathrm{W} 059^{\circ} 42^{\prime} 52,1^{\prime \prime}\end{array}$ & Vic. Fábio Lucena Km 26 & Coffee & Top \\
\hline 5 & $\begin{array}{l}\mathrm{S} 07^{\circ} 10^{\prime} 4,4^{\prime \prime} \\
\mathrm{W} 59^{\circ} 42^{\prime} 55,4^{\prime \prime}\end{array}$ & Vic. Fábio Lucena Km 28 & Pasture & hillside \\
\hline 6 & $\begin{array}{l}\text { S } 07^{\circ} 12^{\prime} 28,4^{\prime \prime} \\
\text { W } 059^{\circ} 40^{\prime} 22,3^{\prime \prime}\end{array}$ & Vic. Paredão Km 34 & Capoeira & Top \\
\hline
\end{tabular}

1 Vic. $=$ Vicinal. amount of iron corresponding to the Gt (Dick, 1986), according to the equations:

$[(\mathrm{Gt} / \mathrm{Gt}+\mathrm{Hm})] \times\left(\mathrm{Fe}_{\mathrm{d}} \%-\mathrm{Fe}_{\mathrm{o}} \%\right)=\% \mathrm{FeGt}$

$\mathrm{FeGt} \% \times 1.59=\mathrm{FeOOH}=\% \mathrm{Gt}$

FeGt $\%-\left(\mathrm{Fe}_{\mathrm{d}} \%-\mathrm{Fe}_{\mathrm{o}} \%\right)=\mathrm{FeHm} \%$

$\mathrm{FeHm} \% \times 1.43=\mathrm{Fe}_{2} \mathrm{O}_{3}=\mathrm{Hm} \%$

$\mathrm{Al}$ and Fe were extracted from FADS by digestion with $\mathrm{H}_{2} \mathrm{SO}_{4} 1: 1$ and the $\mathrm{Si}$ by subsequent alkaline dissolution. The results were expressed as oxides $\left(\mathrm{Al}_{2} \mathrm{O}_{3}, \mathrm{Fe}_{2} \mathrm{O}_{3}\right.$ and $\left.\mathrm{SiO}_{2}\right)$ according to Empresa Brasileira de Pesquisa Agropecuária - EMBRAPA (1979). The determination of dithionite iron $\left(\mathrm{Fe}_{\mathrm{d}}\right)$ followed the methodology of Mehra and Jackson (1960), and the determination of the iron oxalate $\left(\mathrm{Fe}_{\mathrm{o}}\right)$ followed the method of Camargo et al. (1986).

The data were submitted to principal component analysis (PCA), with the aim of summarizing the values of the studied attributes at various environments. For this purpose, the initial set of 32 variables has become characterized by two new latent variables (CP1 and CP2), which has enabled the location in two-dimensional figures (ordering of accesses by principal components). The suitability of this analysis is verified by the total information of the original variables; it is retained in the main components that show eigenvalues superior or inferior to the unit, and not having relevant information. All multivariate statistical analyses were processed in the STATISTICA software version 7.0 (STATSOFT, Inc., 2004). 


\section{Results and discussion}

\subsection{Physical and chemical attributes}

Regarding the DAE particle size fractions, it was noted silt and clay predominance with a trend to increase in depth of clay fraction from anthropogenic horizon to the subsurface one. Contrarily, the silt fraction had different behavior, except only for the P3, which presented dominance of silt fraction in anthropic and subsurface horizons (Table 2). The P5 presented a coarse sand fraction dominance, in which a clear variation in texture was verified due to DAE position within the relief, because of colluvial materials along the slope (Table 2). Silva et al. (2012) studied DAEs of Ultisols in Southwestern Amazon and observed sand fraction predominance in all horizons.

The silt/clay ratio is used as an auxiliary index to indicate soil weathering degree; thus, the higher the value of this ratio, the smaller is the degree of weathering (Jacomine, 2005). The silt/clay ratio in the studied profiles showed higher values in the anthropic horizon than in the subsurface one for all profiles, what indicates the lower degree of

\section{Table 2}

Physical attributes profiles of Archeological Dark Earth sites region of Apuí, southern of Amazonas state, Brazil.

\begin{tabular}{|c|c|c|c|c|c|c|c|c|}
\hline Hor. $^{\mathrm{a}}$ & $\begin{array}{l}\text { Depth } \\
(\mathrm{cm})\end{array}$ & Gravel & $\begin{array}{l}\text { Fine } \\
\text { sand }\end{array}$ & $\begin{array}{l}\text { Silt } \\
\mathrm{g} \mathrm{kg}^{-1}\end{array}$ & Clay & Silt/clay & $\mathrm{WDC}^{\mathrm{b}}$ & $\mathrm{DF}^{\mathrm{c}} \%$ \\
\hline \multicolumn{9}{|c|}{ P1-Typic Hapludox (Yellow Latosol dystrophic anthropic, clay texture) } \\
\hline $\mathrm{Ap}_{1}$ & $0-15$ & 120.38 & 35.42 & 513.14 & 331.07 & 1.55 & 170.2 & 48.59 \\
\hline $\mathrm{Ap}_{2}$ & $15-34$ & 75.00 & 31.22 & 456.82 & 436.96 & 1.05 & 143.04 & 67.26 \\
\hline $\mathrm{AB}$ & $34-63$ & 54.20 & 26.59 & 339.89 & 579.32 & 0.59 & 252.72 & 56.37 \\
\hline BA & 63-91 & 52.39 & 26.52 & 302.87 & 618.21 & 0.49 & 4.28 & 99.30 \\
\hline $\mathrm{Bw}_{1}$ & $91-117$ & 48.52 & 26.01 & 275.89 & 649.57 & 0.43 & 3.44 & 99.47 \\
\hline $\mathrm{Bw}_{2}$ & $117-152+$ & 50.16 & 27.47 & 295.27 & 627.09 & 0.47 & 0.56 & 99.91 \\
\hline \multicolumn{9}{|c|}{ P2-Typic Paleudult (Yellow Argisol eutrophic typical, clay texture, A anthropic) } \\
\hline $\mathrm{Ap}_{1}$ & $0-15$ & 60.64 & 36.22 & 519.76 & 383.38 & 1.37 & 229.20 & 40.21 \\
\hline $\mathrm{Ap}_{2}$ & $19-30$ & 56.83 & 33.08 & 39 & 512 & 0.78 & 318.96 & 37.81 \\
\hline $\mathrm{AB}$ & $30-48$ & 39.70 & 21.73 & 317.76 & 620.81 & 0.51 & 204.36 & 67.08 \\
\hline $\mathrm{Bt}_{1}$ & $48-66$ & 21.03 & 18.09 & 278.94 & 681.95 & 0.41 & 492.04 & 27.84 \\
\hline $\mathrm{Bt}_{2}$ & $66-100$ & 19.71 & 17.85 & 287.44 & 675.00 & 0.43 & 185.56 & 72.50 \\
\hline $\mathrm{Bt}_{3}$ & $100-130^{+}$ & 18.38 & 14.89 & 285.73 & 681.00 & 0.42 & 604.68 & 11.20 \\
\hline \multicolumn{9}{|c|}{ P3-Typic Paleudult (Yellow Argisol dystrophic typical, silty texture, A anthropic) } \\
\hline $\mathrm{Ap}_{1}$ & $0-21$ & 25.70 & 60.43 & 585.58 & 328.25 & 2.51 & 37.32 & 94.10 \\
\hline $\mathrm{Ap}_{2}$ & $21-36$ & 67.16 & 29.44 & 692.08 & 211.32 & 3.28 & 97.04 & 54.07 \\
\hline$A B$ & $36-58$ & 61.56 & 29.91 & 655.21 & 253.32 & 2.60 & 85.4 & 66.28 \\
\hline $\mathrm{Bt}_{1}$ & 58-91 & 61.97 & 31.21 & 645.03 & 261.79 & 2.47 & 3.96 & 98.48 \\
\hline $\mathrm{BCr}$ & $91-120+$ & 63.94 & 30.15 & 618.60 & 287.31 & 2.15 & 0.20 & 99.93 \\
\hline \multicolumn{9}{|c|}{ P4-Typic Paleudult (Yellow Argisol dystrophic typical, clay texture, A anthropic) } \\
\hline $\mathrm{Ap}_{1}$ & $0-19$ & 107.99 & 223.99 & 304.10 & 363.92 & 0.84 & 81.56 & 77.58 \\
\hline $\mathrm{BA}$ & $19-41$ & 155.72 & 104.15 & 266.59 & 473.53 & 0.57 & 31.36 & 93.37 \\
\hline $\mathrm{Bt}_{1}$ & $41-67$ & 118.83 & 65.88 & 391.44 & 423.85 & 2.18 & 1.36 & 99.67 \\
\hline $\mathrm{Bt}_{2}$ & 67-104 & 107.75 & 59.15 & 233.90 & 599.20 & 0.39 & 0.44 & 99.92 \\
\hline $\mathrm{Bt}_{3}$ & $104-147^{+}$ & 99.78 & 55.84 & 298.48 & 545.89 & 0.55 & 0.40 & 99.92 \\
\hline
\end{tabular}

P5-Typic Udipsamments (Regolithic Neosol dystrophic typical, sandy medium texture, A anthropic)

\begin{tabular}{lccccccrc}
$\mathrm{Ap}_{1}$ & $0-18$ & 484.09 & 296.22 & 139.63 & 80.05 & 1.74 & 1.04 & 98.70 \\
$\mathrm{Ap}_{2}$ & $18-31$ & 500.88 & 295.61 & 124.90 & 78.60 & 1.61 & 3.96 & 94.96 \\
$\mathrm{AC}$ & $31-49$ & 519.28 & 304.18 & 94.50 & 82.04 & 1.15 & 19.44 & 76.30 \\
$\mathrm{C}_{1}$ & $49-70$ & 546.21 & 298.98 & 81.74 & 73.07 & 1.21 & 2.08 & 97.15 \\
$\mathrm{C}_{2}$ & $70-90$ & 542.55 & 278.75 & 64.21 & 114.49 & 0.57 & 12.24 & 89.30 \\
$\mathrm{C}_{3}$ & $90-116$ & 506.85 & 285.05 & 98.66 & 109.44 & 0.90 & 63.16 & 42.28 \\
$\mathrm{C}_{4}$ & $116-135^{+}$ & 477.50 & 270.72 & 70.60 & 181.19 & 0.39 & 119.00 & 34.32 \\
\multicolumn{7}{c}{ P6-Typic Paleudult } & (Yellow Argisol dystrophic typical, clay texture, A anthropic) \\
$\mathrm{Ap}_{1}$ & $0-15$ & 220.76 & 140.69 & 355.11 & 283.44 & 1.25 & 92.52 & 67.35 \\
$\mathrm{AB}$ & $19-30$ & 178.78 & 137.57 & 273.98 & 409.68 & 0.67 & 172.44 & 57.90 \\
$\mathrm{Bt}_{1}$ & $30-48$ & 125.15 & 80.26 & 240.14 & 554.45 & 0.43 & 208.28 & 62.43 \\
$\mathrm{Bt}_{2}$ & $48-66$ & 131.96 & 67.06 & 225.49 & 575.49 & 0.39 & 161.28 & 71.97 \\
$\mathrm{Bt}_{3}$ & $66-100$ & 124.38 & 73.53 & 265.84 & 536.24 & 0.50 & 408.04 & 23.90 \\
$\mathrm{Bt}_{4}$ & $100-130^{+}$ & 126.80 & 75.77 & 228.42 & 569.01 & 0.40 & 293.56 & 48.40 \\
\hline
\end{tabular}

a Hor. = horizons

b $\mathrm{WDC}=$ water dispersible clay.

${ }^{c} \mathrm{DF}=$ degree flocculation. weathering, reinforcing its anthropogenic origin. The P3 showed values silt/clay high throughout the profile, indicating a lower degree of weathering when compared to the other profiles (Table 2).

Water dispersible clay (WDC) presented for P1, P3 and P4 higher values in the first horizons. This behavior comes from the higher contribution of iron oxides at greater depths in the most weathered soils; and P2, P5 and P6 showed high values with increased depth; in this case, indicating greater movement of clay along the soil profile. The stability can be noted through DF for aggregates presented in P3, P4 and P5, in anthropic horizons, caused by the direct contribution of OM in this soil (Table 2). These results are in agreement with Lima et al. (2002) and Santos et al. (2013), who stated that severe weather conditions favor destruction of soil aggregates, although the organization state of the structure is highly developed.

The $\mathrm{Ca}$ values in the anthropic horizon ranged from 11.0 to $122.0 \mathrm{mmol} \mathrm{kg}^{-1}$, with a decrease in depth in the subsurface horizons. The Mg varied from 4.0 to $15.0 \mathrm{mmol} \mathrm{kg}^{-1}$ in the anthropogenic horizon, in which values decrease with depth increases (Table 3). The P2 was the one with the highest Ca value; it is possibly due to the incorporation of bones rich in Ca, or due to the higher affinity of Ca by the exchange surfaces, resulting in lower leaching as highlighted by Barros et al. (2012). The other profiles that presented low value may be reflexes of time variation and density of human occupation in these areas (Campos et al., 2012).

The $\mathrm{K}$ contents were very low ranging from 0.10 to $1.70 \mathrm{mmol} \mathrm{kg}^{-1}$. Falcão and Borges (2006) and Barros et al. (2012) also found such K values in DAEs. This may be a limiting element in crop production grown in DAEs. Considering that the appropriate average levels of $\mathrm{Ca}$, $\mathrm{Mg}$ and $\mathrm{K}$ are $28 \mathrm{mmol} \mathrm{kg}^{-1}, 8 \mathrm{mmol} \mathrm{kg}{ }^{-1}$, and $2.3 \mathrm{mmol} \mathrm{kg}^{-1}$, respectively, it can be inferred that low $\mathrm{K}$ values found in all the DAE profiles were greater or equal to $1.40 \mathrm{mmol} \mathrm{kg}{ }^{-1}$, presenting high nutritional imbalance for plant growth and production.

The $\mathrm{pH}$ profiles of DAEs is acids, with values between 5.6 to 4.10 connected to organic complexes that have provided this acidification through the release of $\mathrm{H}^{+}$in the process of decomposition of organic matter. In this sense, noted that the $\mathrm{Al}^{3+}$ and consequently the saturation by aluminum ( $\mathrm{m} \%$ ) are found in very low concentrations, indicating that these are complexed in compounds of organic matter. The acidity potential features and concentrations, are usually found in Amazonian soils (Santos et al., 2013).

The CEC had high values for anthropogenic horizons, pointing out P1 and P2, which presented the highest ones. On the other hand, P5 presented the lowest values (Table 3 ). It is important to emphasize the decrease on CEC values with the increase in depth; this behavior can be justified by larger amounts of highly reactive organic matter originated from pyrogenic carbon in anthropogenic horizon of these soils (Glaser et al., 2000; Cunha et al., 2007). Liang et al. (2006) studying the Amazon DAE solos showed that the charge of CEC is much larger in relation to adjacent soils poor in the Amazon due to higher concentrations of organic carbon.

The highest percentages of V\% were observed at P2, which is classified as eutrophic, and the other profiles as dystrophic, implying in low fertility of these profiles. Campos et al. (2011) found profiles with eutrophic characteristics among the DAE profiles in study; Santos et al. (2013) found profiles ranging from eutrophic to dystrophic, which reinforces the idea of variation in anthropogenic soils.

Concerning the P contents, P1, P2 and P3 showed elevated values that ranged between 84.0 and $173.0 \mathrm{mg} \mathrm{dm}^{-3}$, whereas in P4, P5 and P6 they varies from 22.0 to $65.0 \mathrm{mg} \mathrm{dm}^{-3}$ (Table 3 ). In summary, these numbers are much higher than levels found in non-anthropogenic soils of the Amazonas, in which P concentrations typically lower than $5 \mathrm{mg} \mathrm{kg}^{-1}$ are observed (Rodrigues, 1996); indicating a decisive anthropogenic influence in DAE formation. It is known that phosphorus presents organic origin, which may explain its higher concentrations in anthropic horizons, and transport to the subsurface horizon may still occur. Lima et al. (2002) justify this behavior with the occurrence of intense 
Table 3

Chemical attributes of profiles of Archeological Dark Earth sites in region of Apuí, southern of Amazonas state, Brazil.

\begin{tabular}{|c|c|c|c|c|c|c|c|c|c|c|c|c|c|c|c|c|}
\hline \multirow[t]{2}{*}{ Hor. } & \multirow{2}{*}{$\begin{array}{l}\text { Depth } \\
\mathrm{cm}\end{array}$} & \multirow[t]{2}{*}{$\mathrm{pH} \mathrm{H} \mathrm{H}_{2} \mathrm{O}$} & \multirow[t]{2}{*}{$\mathrm{pH} \mathrm{KCl}$} & \multirow[t]{2}{*}{$\Delta \mathrm{pH}$} & $\mathrm{Ca}$ & $\mathrm{Mg}$ & $\mathrm{K}$ & SB & Al & $\mathrm{H}+\mathrm{Al}$ & CEC & $\mathrm{V}$ & $\mathrm{m}$ & $\mathrm{P}$ & TOC & $\mathrm{OM}$ \\
\hline & & & & & \multicolumn{7}{|c|}{$\mathrm{mmol}_{\mathrm{c}} \mathrm{kg}^{-1}$} & \multicolumn{2}{|l|}{$\%$} & $\mathrm{mg} \mathrm{dm}{ }^{-3}$ & \multicolumn{2}{|c|}{$\mathrm{g} \mathrm{dm}^{-3}$} \\
\hline \multicolumn{17}{|c|}{ P1 Typic Hapludox - (Yellow Latosol dystrophic anthropic, clay texture) } \\
\hline $\mathrm{Ap}_{1}$ & $0-15$ & 4.50 & 4.30 & -0.20 & 48.00 & 7.00 & 1.30 & 56.30 & 0.40 & 109.00 & 165.30 & 34.10 & 2.26 & 166.00 & 37.70 & 65.00 \\
\hline $\mathrm{Ap}_{2}$ & $15-34$ & 4.10 & 4.10 & 0.00 & 13.00 & 4.00 & 0.60 & 17.60 & 1.95 & 121.00 & 138.60 & 12.70 & 1.40 & 84.00 & 24.94 & 43.00 \\
\hline$A B$ & $34-63$ & 4.10 & 4.10 & 0.00 & 6.00 & 2.00 & 0.50 & 8.50 & 2.05 & 98.00 & 106.50 & 8.00 & 1.92 & 94.00 & 10.44 & 18.00 \\
\hline BA & $63-91$ & 4.10 & 4.10 & 0.00 & 8.00 & 3.00 & 0.60 & 11.60 & 1.35 & 88.00 & 99.60 & 11.60 & 1.35 & 117.00 & 6.96 & 12.00 \\
\hline $\mathrm{Bw}_{1}$ & $91-117$ & 4.40 & 4.20 & -0.20 & 11.00 & 4.00 & 0.20 & 15.20 & 0.75 & 58.00 & 73.20 & 20.80 & 1.02 & 135.00 & 4.06 & 7.00 \\
\hline $\mathrm{Bw}_{2}$ & $117-152+$ & 4.40 & 4.20 & -0.20 & 10.00 & 4.00 & 0.20 & 14.20 & 0.60 & 58.00 & 72.20 & 19.70 & 0.83 & 133.00 & 3.48 & 6.00 \\
\hline \multicolumn{17}{|c|}{ P2-Typic Paleudult (Yellow Argisol eutrophic typical, clay texture, A anthropic) } \\
\hline $\mathrm{Ap}_{1}$ & $0-15$ & 5.20 & 5.10 & -0.10 & 122.00 & 15.00 & 1.30 & 138.30 & 0.00 & 58.00 & 196.30 & 70.50 & 0.00 & 144.00 & 32.48 & 56.00 \\
\hline $\mathrm{Ap}_{2}$ & $19-30$ & 5.10 & 5.00 & -0.10 & 92.00 & 14.00 & 1.00 & 107.00 & 0.00 & 58.00 & 165.00 & 64.80 & 0.00 & 173.00 & 18.56 & 32.00 \\
\hline$A B$ & $30-48$ & 4.90 & 4.70 & -0.20 & 62.00 & 13.00 & 0.90 & 75.90 & 0.00 & 52.00 & 127.90 & 59.30 & 0.00 & 159.00 & 9.28 & 16.00 \\
\hline $\mathrm{Bt}_{1}$ & $48-66$ & 4.80 & 4.50 & -0.30 & 52.00 & 8.00 & 0.90 & 60.90 & 0.00 & 52.00 & 112.90 & 53.90 & 0.00 & 143.00 & 5.22 & 9.00 \\
\hline $\mathrm{Bt}_{2}$ & $66-100$ & 4.80 & 4.50 & -0.30 & 47.00 & 6.00 & 1.50 & 54.50 & 0.00 & 47.00 & 101.50 & 53.70 & 0.00 & 152.00 & 4.64 & 8.00 \\
\hline $\mathrm{Bt}_{3}$ & $100-130^{+}$ & 4.80 & 4.60 & -0.20 & 42.00 & 6.00 & 1.70 & 49.70 & 0.00 & 42.00 & 91.70 & 54.20 & 0.00 & 157.00 & 3.48 & 6.00 \\
\hline \multicolumn{17}{|c|}{ P3-Typic Paleudult (Yellow Argisol dystrophic typical, silty texture, A anthropic) } \\
\hline $\mathrm{Ap}_{1}$ & $0-21$ & 4.50 & 4.20 & -0.30 & 41.00 & 8.00 & 1.40 & 50.40 & 0.50 & 98.00 & 148.40 & 34.00 & 2.54 & 125.00 & 33.06 & 57.00 \\
\hline $\mathrm{Ap}_{2}$ & $21-36$ & 4.50 & 4.30 & -0.20 & 14.00 & 5.00 & 0.50 & 19.50 & 1.10 & 98.00 & 117.50 & 16.60 & 0.93 & 61.00 & 23.78 & 41.00 \\
\hline $\mathrm{AB}$ & $36-58$ & 4.40 & 4.20 & -0.20 & 6.00 & 3.00 & 0.50 & 9.50 & 1.20 & 98.00 & 107.50 & 8.80 & 1.11 & 57.00 & 16.24 & 28.00 \\
\hline $\mathrm{Bt}_{1}$ & 58-91 & 4.40 & 4.30 & -0.10 & 2.00 & 1.00 & 0.40 & 3.40 & 0.80 & 64.00 & 67.40 & 5.00 & 1.18 & 68.00 & 7.54 & 13.00 \\
\hline $\mathrm{BCr}$ & $91-120+$ & 4.41 & 4.40 & -0.01 & 2.00 & 1.00 & 0.30 & 3.30 & 0.80 & 64.00 & 67.30 & 4.90 & 1.18 & 68.00 & 6.38 & 11.00 \\
\hline \multicolumn{17}{|c|}{ P4-Typic Paleudult (Yellow Argisol dystrophic typical, clay texture, A anthropic) } \\
\hline $\mathrm{Ap}_{1}$ & $0-19$ & 4.30 & 4.10 & -0.20 & 16.00 & 5.00 & 0.80 & 21.80 & 1.20 & 109.00 & 130.80 & 16.70 & 2.76 & 65.00 & 18.56 & 32.00 \\
\hline $\mathrm{BA}$ & $19-41$ & 4.20 & 4.00 & -0.20 & 11.00 & 4.00 & 0.10 & 15.10 & 1.05 & 64.00 & 79.10 & 19.10 & 1.32 & 34.00 & 6.38 & 11.00 \\
\hline $\mathrm{Bt}_{1}$ & $41-67$ & 4.20 & 4.10 & -0.10 & 11.00 & 4.00 & 0.10 & 15.10 & 0.65 & 42.00 & 57.10 & 26.40 & 1.13 & 41.00 & 4.06 & 7.00 \\
\hline $\mathrm{Bt}_{2}$ & 67-104 & 4.25 & 4.20 & -0.05 & 10.00 & 4.00 & 0.10 & 14.10 & 0.45 & 34.00 & 48.10 & 29.30 & 0.93 & 41.00 & 3.48 & 6.00 \\
\hline $\mathrm{Bt}_{3}$ & $104-147^{+}$ & 4.30 & 4.20 & -0.10 & 9.00 & 4.00 & 0.10 & 13.10 & 0.40 & 34.00 & 47.10 & 27.80 & 0.84 & 32.00 & 3.48 & 6.00 \\
\hline \multicolumn{17}{|c|}{ P5-Typic Udipsamments (Regolithic Neosol dystrophic typical, sandy medium texture, A anthropic) } \\
\hline $\mathrm{Ap}_{1}$ & $0-18$ & 5.30 & 4.30 & -1.00 & 50.00 & 10.00 & 0.50 & 60.50 & 0.00 & 31.00 & 91.50 & 66.10 & 0.00 & 55.00 & 17.98 & 31.00 \\
\hline $\mathrm{Ap}_{2}$ & $18-31$ & 5.30 & 4.40 & -0.90 & 55.00 & 10.00 & 0.30 & 65.30 & 0.00 & 31.00 & 96.30 & 67.80 & 0.00 & 55.00 & 16.24 & 28.00 \\
\hline$A C$ & $31-49$ & 5.50 & 5.20 & -0.30 & 35.00 & 6.00 & 0.20 & 41.20 & 0.00 & 28.00 & 69.20 & 59.50 & 0.00 & 35.00 & 8.70 & 15.00 \\
\hline $\mathrm{C}_{1}$ & $49-70$ & 5.30 & 5.20 & -0.10 & 14.00 & 4.00 & 0.10 & 18.10 & 0.00 & 20.00 & 38.10 & 47.50 & 0.00 & 24.00 & 4.06 & 7.00 \\
\hline $\mathrm{C}_{2}$ & $70-90$ & 5.30 & 5.20 & -0.10 & 11.00 & 3.00 & 0.10 & 14.10 & 0.00 & 16.00 & 30.10 & 46.80 & 0.00 & 39.00 & 2.32 & 4.00 \\
\hline$C_{3}$ & $90-116$ & 5.15 & 5.10 & -0.05 & 11.00 & 3.00 & 0.10 & 14.10 & 0.00 & 16.00 & 30.10 & 46.80 & 0.00 & 45.00 & 2.32 & 4.00 \\
\hline $\mathrm{C}_{4}$ & $116-135^{+}$ & 5.10 & 5.00 & -0.10 & 11.00 & 3.00 & 0.10 & 14.10 & 0.05 & 1800 & 32.10 & 43.90 & 0.15 & 52.00 & 2.32 & 4.00 \\
\hline \multicolumn{17}{|c|}{ P6-Typic Paleudult (Yellow Argisol dystrophic typical, clay texture, A anthropic) } \\
\hline $\mathrm{Ap}_{1}$ & $0-15$ & 5.60 & 5.50 & -0.10 & 70.00 & 11.00 & 0.70 & 81.70 & 0.00 & 31.00 & 112.70 & 72.50 & 0.00 & 33.00 & 19.72 & 34.00 \\
\hline $\mathrm{AB}$ & $19-30$ & 4.90 & 4.70 & -0.20 & 30.00 & 8.00 & 0.30 & 38.30 & 0.05 & 42.00 & 80.30 & 47.70 & 0.06 & 22.00 & 9.86 & 17.00 \\
\hline $\mathrm{Bt}_{1}$ & $30-48$ & 4.80 & 4.60 & -0.20 & 18.00 & 8.00 & 0.20 & 26.20 & 0.05 & 31.00 & 57.20 & 45.80 & 0.08 & 53.00 & 5.22 & 9.00 \\
\hline $\mathrm{Bt}_{2}$ & $48-66$ & 4.00 & 4.60 & -0.10 & 13.00 & 7.00 & 0.20 & 20.20 & 0.05 & 31.00 & 51.20 & 39.50 & 0.09 & 64.00 & 4.06 & 7.00 \\
\hline $\mathrm{Bt}_{3}$ & $66-100$ & 4.20 & 4.10 & -0.10 & 4.00 & 3.00 & 0.10 & 7.10 & 1.20 & 42.00 & 49.10 & 14.50 & 2.44 & 41.00 & 3.48 & 6.00 \\
\hline $\mathrm{Bt}_{4}$ & $100-130^{+}$ & 4.20 & 4.10 & -0.10 & 3.00 & 2.00 & 0.10 & 5.10 & 1.15 & 42.00 & 47.10 & 10.80 & 2.44 & 22.00 & 2.90 & 5.00 \\
\hline
\end{tabular}

bioturbation in DAEs, which results in redistribution of $\mathrm{P}$ in profile, enriching subsurface horizons. Lehmann et al. (2003) claims that occur high levels of organic P available and retained on OM in soils of DAEs.

Organic carbon and organic matter contents varied by depth, with higher levels in the anthropic horizon. P1, P2 and P3 showed decreasing values of organic matter in depth (Table 3 ), in agreement with the results of Cunha et al. (2007). According to Campos et al. (2012), the high content of organic carbon in the areas of DAEs is attributed to anthropogenic changes of which this soil has suffered along formation.

\subsection{Mineralogy of iron oxides}

Sulfuric acid digestion revealed variation in $\mathrm{Si}$, Fe and $\mathrm{Al}$ oxides of the DAE profiles. The Al contents were higher in P1, P2 and P3, showing the richness of oxides in these soils. Contrarily, $\mathrm{P} 4$ presented predominance of Fe; in P6, Si showed the highest values; while in P5, Si has prevailed in anthropogenic horizon, and $\mathrm{Al}$ had higher levels in the subsurface one (Table 4). Santos et al. (2013) observed a predominant presence of $\mathrm{Al}_{2} \mathrm{O}_{3}$ in studied profiles.

The $\mathrm{Fe}_{2} \mathrm{O}_{3}$ content present in anthropogenic horizons ranged from 30.64 to $90.70 \mathrm{~g} \mathrm{~kg}^{-1}$ and in the subsurface horizons ranged from 45.55 to $124.36 \mathrm{~g} \mathrm{~kg}^{-1}$. These limits are higher than those found by Silva et al. (2011), studying man-made soils in the Amazon, they found values of $\mathrm{Fe}_{2} \mathrm{O}_{3}$ ranging from 42.9 to $99.3 \mathrm{~g} \mathrm{~kg}^{-1}$, in subsurface horizons, these values are considered low, but normally found in local soils. The free iron contents $\left(\mathrm{Fe}_{\mathrm{d}}\right)$ predominated over the forms of low crystallinity iron $\left(\mathrm{Fe}_{\mathrm{o}}\right)$ (Table 4$)$.

The ratio Feo/Fed indicates the proportion of pedogenic iron oxides that have low crystallinity, and its raise corresponds to a decrease in crystalline iron oxides (Schwertmann and Kämpf, 1985). Furthermore, the ratio $\mathrm{Fe}_{\mathrm{d}} / \mathrm{Fe}_{\mathrm{t}}$ infers the proportion of iron already released by weathering of primary minerals and built into the pedogenic form of iron oxides, forming thus an indication of soil weathering degree. The ratio $\mathrm{Fe}_{\mathrm{o}} / \mathrm{Fe}_{\mathrm{d}}$ presented higher values in $\mathrm{P} 1, \mathrm{P} 2, \mathrm{P} 3$ and $\mathrm{P} 5$, indicating a larger iron content of low crystallinity $(>0.05$ ) (Table 4 ), and it can be considered as an indicator of anthropogenic activities, especially burning of materials at higher temperatures for a period.

It is noteworthy that these soils also have higher organic carbon contents, which affects the $\mathrm{Fe}_{\mathrm{o}} / \mathrm{Fe}_{\mathrm{d}}$ ratio, since organic matter inhibits crystallization during iron oxides formation (Meirelles et al., 2012). Another reason might be the large volume of rainfall in the Amazonas region, raising reducer microenvironments under undisturbed conditions, which would lead to iron oxide dissolution and leaching into deeper layers and neo-formation of new minerals (Kämpf and Curi, 2000; Silva Neto et al., 2008). High values in all profiles can be observed in the $\mathrm{Fe}_{\mathrm{d}} / \mathrm{Fe}_{\mathrm{t}}$ ratio (Table 4 ). 
Table 4

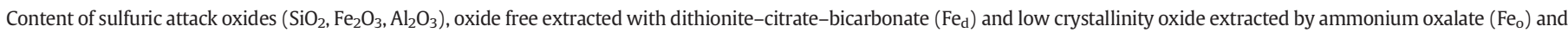
the relationship between them at sites profiles Archeological Dark Earth in region of Apuí, southern of Amazonas state, Brazil.

\begin{tabular}{|c|c|c|c|c|c|c|c|c|c|c|}
\hline \multirow[t]{2}{*}{ Hor. } & \multirow{2}{*}{$\begin{array}{l}\text { Depth } \\
(\mathrm{cm})\end{array}$} & $\mathrm{SiO}_{2}$ & $\mathrm{Fe}_{2} \mathrm{O}_{3}$ & $\mathrm{Al}_{2} \mathrm{O}_{3}$ & $\mathrm{Fe}_{\mathrm{d}}^{\mathrm{a}}$ & $\mathrm{Fe}_{\mathrm{o}}{ }^{\mathrm{b}}$ & \multirow[t]{2}{*}{$\mathrm{Ki}^{\mathrm{c}}$} & \multirow[t]{2}{*}{$\mathrm{Kr}^{\mathrm{d}}$} & \multirow[t]{2}{*}{$\mathrm{Fe}_{\mathrm{o}} / \mathrm{Fe}_{\mathrm{d}}$} & \multirow[t]{2}{*}{$\mathrm{Fe}_{\mathrm{d}} / \mathrm{Fe}_{\mathrm{t}}^{\mathrm{e}}$} \\
\hline & & \multicolumn{5}{|l|}{$\mathrm{g} \mathrm{kg}^{-1}$} & & & & \\
\hline \multicolumn{11}{|c|}{ P1-Typic Hapludox (Yellow Latosol dystrophic anthropic, clay texture) } \\
\hline $\mathrm{Ap}_{1}$ & $0-15$ & 140.50 & 63.49 & 215.00 & 37.38 & 6.69 & 1.11 & 0.55 & 0.18 & 0.59 \\
\hline $\mathrm{Bw}_{2}$ & $91-117$ & 294.50 & 77.40 & 255.00 & 42.08 & 16.80 & 1.91 & 0.97 & 0.40 & 0.54 \\
\hline \multicolumn{11}{|c|}{ P2-Typic Paleudult (Yellow Argisol eutrophic typical, clay texture, A anthropic) } \\
\hline $\mathrm{Ap}_{1}$ & $0-15$ & 20.50 & 90.70 & 210.00 & 51.47 & 11.26 & 0.17 & 0.08 & 0.22 & 0.57 \\
\hline $\mathrm{Bt}_{2}$ & $48-66$ & 289.50 & 124.36 & 250.00 & 74.77 & 11.67 & 1.97 & 0.88 & 0.16 & 0.60 \\
\hline \multicolumn{11}{|c|}{ P3-Typic Paleudult (Yellow Argisol dystrophic typical, silty texture, A anthropic) } \\
\hline $\mathrm{Ap}_{1}$ & $0-21$ & 17.00 & 52.00 & 170.00 & 24.02 & 19.33 & 0.17 & 0.08 & 0.80 & 0.46 \\
\hline $\mathrm{Bt}_{2}$ & 58-91 & 30.50 & 45.55 & 150.00 & 24.38 & 16.56 & 0.35 & 0.17 & 0.68 & 0.54 \\
\hline \multicolumn{11}{|c|}{ P4-Typic Paleudult (Yellow Argisol dystrophic typical, clay texture, A anthropic) } \\
\hline $\mathrm{Ap}_{1}$ & $0-19$ & 131.00 & 54.22 & 90.00 & 32.87 & 5.79 & 2.47 & 1.05 & 0.18 & 0.61 \\
\hline $\mathrm{Bt}_{2}$ & $41-67$ & 108.00 & 98.96 & 85.00 & 54.18 & 9.87 & 2.16 & 0.73 & 0.18 & 0.55 \\
\hline \multicolumn{11}{|c|}{ P5-Typic Udipsamments (Regolithic Neosol dystrophic typical, sandy medium texture, A anthropic) } \\
\hline $\mathrm{Ap}_{1}$ & $0-18$ & 13.50 & 30.64 & 35.00 & 17.52 & 2.28 & 0.66 & 0.25 & 0.13 & 0.57 \\
\hline $\mathrm{C}_{2}$ & $49-70$ & 5.50 & 115.69 & 25.00 & 56.71 & 17.95 & 0.37 & 0.06 & 0.32 & 0.49 \\
\hline \multicolumn{11}{|c|}{ P6-Typic Paleudult (Yellow Argisol dystrophic typical, clay texture, A anthropic) } \\
\hline $\mathrm{Ap}_{1}$ & $0-15$ & 88.00 & 57.85 & 125.00 & 59.95 & 1.22 & 1.20 & 0.54 & 0.02 & 1.04 \\
\hline $\mathrm{Bt}_{2}$ & $30-48$ & 56.50 & 81.02 & 200.00 & 39.37 & 4.08 & 0.48 & 0.22 & 0.10 & 0.49 \\
\hline
\end{tabular}

${ }^{\text {a }} \mathrm{Fe}_{\mathrm{o}}=\mathrm{Fe}_{2} \mathrm{O}_{3}$ extracted by ammonium oxalate.

b $\mathrm{Fe}_{\mathrm{d}}=\mathrm{Fe}_{2} \mathrm{O}_{3}$ extracted by ditionite-citrate-bicarbonate.

c $\mathrm{Ki}=$ relationship $\left(\% \mathrm{SiO}_{2} \times 1.7\right) / \% \mathrm{Al}_{2} \mathrm{O}_{3}$.

d $\mathrm{Kr}=\left(\% \mathrm{SiO}_{2} \times 1.7\right) /\left(\% \mathrm{Al}_{2} \mathrm{O}_{3}+\% \mathrm{Fe}_{2} \mathrm{O}_{3} \times 0.64\right)$.

e $\mathrm{Fe}_{\mathrm{t}}=$ total iron on values $\mathrm{Fe}_{2} \mathrm{O}_{3}$.

According to Resende and Santana (1988), Kr values lower than 0.75 define the soil with oxidic mineralogical characteristics and, higher than 0.75 with kaolinitic ones, while values close to 1.0 emphasize a balance between these two minerals. Kr value in the anthropogenic horizon presented oxidic characteristics, except for $\mathrm{P} 4$, had a balance between the two minerals (Table 4).

Regarding the crystallinity degree and particle size, it is known that the larger the diffraction peak, the lower the crystal size and the worse the crystallinity degree. Crystallinity differences were observed between the surface layers of each profile, as well as between profiles. The highest values of MCD was found on Hm 012, in Gt occurred variation between the reflections from 16.00 to $45.30 \mathrm{~nm}$ (Table 5). Resende (1976) found for Gt in several Oxisols of Brazil, mean values from 15 to $38 \mathrm{~nm}$ for $\mathrm{d}_{110}$ and $\mathrm{d}_{111}$ reflections, respectively. The MCD results of Gt in the DAE values exceeded the average of Brazilian soils.

Interestingly for $\mathrm{WHH}$, the results were inverse to the $\mathrm{MCD}$, that is, where larger MCD values occurred (Table 5). According to the claims of Fitzpatrick and Schwertmann (1982), the highest degree of crystallinity is evidenced by the higher MCD and lower WHH. In this case, it appears that $\mathrm{Hm}$ is presented with a greater degree of crystallinity due to occurrence of higher values of MCD and lower of WHH in the profiles studied. There is a general trend for the Gt having smaller crystals

Table 5

Crystallographic characteristics of iron oxides in Archeological Dark Earth sites profiles in region of Apuí, southern of Amazonas state, Brazil.

\begin{tabular}{|c|c|c|c|c|c|c|c|c|c|c|c|c|c|c|c|c|}
\hline \multirow[t]{2}{*}{ Hor. } & \multirow[t]{2}{*}{ Depth $(\mathrm{cm})$} & \multicolumn{2}{|l|}{ WHH } & \multicolumn{2}{|l|}{ WHH } & \multicolumn{2}{|l|}{ MCD } & \multicolumn{2}{|l|}{ MCD } & \multicolumn{2}{|l|}{ SSA } & \multicolumn{2}{|l|}{ Is } & \multirow[t]{2}{*}{$\mathrm{Gt} /(\mathrm{Gt}+\mathrm{Hm})$} & \multicolumn{2}{|c|}{ Content } \\
\hline & & Gt 110 & Gt 111 & Hm 110 & $\mathrm{Hm} 012$ & Gt 110 & Gt 111 & Hm 110 & Hm 012 & Gt & $\mathrm{Hm}$ & $\mathrm{Gt}$ & $\mathrm{Hm}$ & & $\mathrm{Gt}$ & $\mathrm{Hm}$ \\
\hline \multicolumn{17}{|c|}{ P1-Typic Hapludox (Yellow Latosol dystrophic anthropic, clay texture) } \\
\hline $\mathrm{Ap}_{1}$ & $0-15$ & 0.21 & 0.20 & 0.27 & 0.16 & 38.80 & 42.40 & 31.60 & 51.30 & 59.31 & 46.92 & 24.29 & 21.40 & 0.55 & 31.20 & 23.40 \\
\hline $\mathrm{Bw}_{2}$ & $91-117$ & 0.37 & 0.32 & 0.32 & 0.15 & 22.40 & 26.80 & 26.90 & 55.00 & 106.34 & 51.53 & 24.68 & 50.94 & 0.65 & 31.30 & 15.10 \\
\hline \multicolumn{17}{|c|}{ P2-Typic Paleudult (Yellow Argisol eutrophic typical, clay texture, A anthropic) } \\
\hline $\mathrm{Ap}_{1}$ & $0-15$ & 0.27 & 0.41 & 0.16 & 0.14 & 30.60 & 21.00 & 52.90 & 74.20 & 76.70 & 28.92 & 16.27 & 12.14 & 0.69 & 74.40 & 30.50 \\
\hline $\mathrm{Bt}_{2}$ & $48-66$ & 0.31 & 0.39 & 0.30 & 0.12 & 26.70 & 22.00 & 28.60 & 68.20 & 88.60 & 46.95 & 18.94 & 55.16 & 0.74 & 99.00 & 31.00 \\
\hline \multicolumn{17}{|c|}{ P3-Typic Paleudult (Yellow Argisol dystrophic typical, silty texture, A anthropic) } \\
\hline $\mathrm{Ap}_{1}$ & $0-21$ & 0.32 & 0.28 & 0.31 & 0.11 & 25.90 & 30.50 & 27.70 & 74.20 & 91.55 & 47.37 & 30.95 & 4.72 & 0.60 & 2.70 & 1.60 \\
\hline $\mathrm{Bt}_{2}$ & $58-91$ & 0.49 & 0.54 & 0.35 & 0.09 & 17.10 & 16.00 & 24.60 & 89.90 & 141.19 & 50.75 & 21.07 & 29.20 & 0.63 & 17.80 & 9.40 \\
\hline \multicolumn{17}{|c|}{ P4-Typic Paleudult (Yellow Argisol dystrophic typical, clay texture, A anthropic) } \\
\hline $\mathrm{Ap}_{1}$ & $0-19$ & 0.18 & 0.34 & 0.35 & 0.09 & 45.30 & 25.20 & 24.60 & 89.90 & 50.15 & 50.75 & 30.95 & 21.40 & 0.65 & 31.60 & 15.10 \\
\hline $\mathrm{Bt}_{2}$ & $41-67$ & 0.21 & 0.25 & 0.45 & 0.09 & 39.00 & 34.10 & 19.20 & 89.90 & 59.03 & 63.03 & 17.45 & 29.66 & 0.71 & 59.40 & 21.60 \\
\hline \multicolumn{17}{|c|}{ P5-Typic Udipsamments (Regolithic Neosol dystrophic typical, sandy medium texture, A anthropic) } \\
\hline $\mathrm{Ap}_{1}$ & $0-18$ & 0.32 & 0.47 & 0.29 & 0.09 & 25.90 & 18.30 & 29.60 & 87.90 & 91.55 & 43.55 & 30.00 & 13.08 & 0.56 & 10.60 & 7.40 \\
\hline$C_{2}$ & $49-70$ & 0.31 & 0.46 & 0.65 & 0.51 & 26.70 & 18.70 & 13.30 & 16.40 & 88.60 & 119.74 & 31.00 & 21.40 & 0.87 & 35.30 & 4.70 \\
\hline \multicolumn{17}{|c|}{ P6-Typic Paleudult (Yellow Argisol dystrophic typical, clay texture, A anthropic) } \\
\hline $\mathrm{Ap}_{1}$ & $0-15$ & 0.29 & 0.28 & 0.29 & 0.13 & 28.50 & 30.50 & 29.50 & 62.60 & 82.68 & 46.64 & 37.60 & 21.40 & 0.64 & 59.40 & 30.50 \\
\hline $\mathrm{Bt}_{2}$ & $30-48$ & 0.29 & 0.35 & 0.25 & 0.11 & 28.50 & 24.50 & 34.30 & 74.20 & 82.68 & 39.96 & 30.90 & 37.88 & 0.72 & 61.40 & 21.00 \\
\hline
\end{tabular}

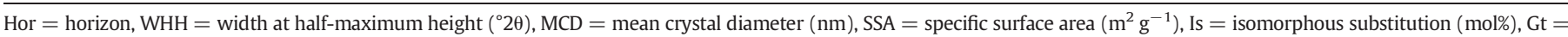
goethite, $\mathrm{Hm}=$ hematite, content $\left(\mathrm{g} \mathrm{kg}^{-1}\right)$. 
than the Hm (Resende et al., 2011), however, in ADEs profiles occurred presence of DMC Gt crystals larger than those of $\mathrm{Hm}$.

The values of the specific surface area (SSA) in Gt remained between 50.15 and $141.19 \mathrm{~m}^{2} \mathrm{~g}^{-1}$ and in the $\mathrm{Hm}$ between 28.92 and $119.74 \mathrm{~m}^{2} \mathrm{~g}^{-1}$ (Table 5). According to Cornell and Schwertmann (1996), the SSA influences the reactivity of iron oxide since the number of existing functional groups on the surface of these minerals that interact with soluble species and gases depends on this attribute.
Mineral isomorphous substitution (Is) means exchange of elements without substantial alteration in its structure. In the DAE profiles of this study, the Is in Gt ranged from 16.27 to $37.60 \mathrm{~mol} \%$, while the Hm ranged from 4.72 to $55.16 \mathrm{~mol} \%$. There is a greater isomorphic substitution rate in $\mathrm{Hm}$ (Table 5), with values above the average for Brazilian soils. In studies on Brazilian soils, Rezende (1980) observed variations on Gt values that ranged from 2 to 33 mol\%; while Kämpf et al. (1988) reported maximum values of $36 \mathrm{~mol} \%$ for goethite and from 4 to $17 \mathrm{~mol} \%$ for hematite.

Table 6

Color measurements by Munsell charts and diffuse reflectance spectra (DRS) profiles of Archeological Dark Earth sites in region of Apuí, southern of Amazonas state, Brazil.

\begin{tabular}{|c|c|c|c|c|c|c|c|c|c|}
\hline \multirow{2}{*}{ Horizon } & \multirow{2}{*}{$\begin{array}{l}\text { Depth } \\
(\mathrm{cm})\end{array}$} & \multicolumn{4}{|c|}{ Munsell } & \multicolumn{4}{|c|}{ DRS } \\
\hline & & Hue & Value & Chroma & Colors & Hue & Value & Chroma & Colors \\
\hline \multicolumn{10}{|c|}{ P1- Typic Hapludox (Yellow Latosol dystrophic anthropic, clay texture) } \\
\hline $\mathrm{Ap}_{1}$ & $0-15$ & 10YR & 2.00 & 1.00 & & 9.99YR & 4.47 & 3.33 & \\
\hline $\mathrm{Ap}_{2}$ & $15-34$ & 10YR & 2.00 & 2.00 & & $0.24 \mathrm{Y}$ & 4.72 & 3.58 & \\
\hline $\mathrm{AB}$ & $34-63$ & 10YR & 3.00 & 2.00 & & 9.92YR & 5.65 & 4.53 & \\
\hline $\mathrm{BA}$ & $63-91$ & 10YR & 3.00 & 2.00 & & 9.88YR & 6.29 & 4.99 & \\
\hline $\mathrm{Bw}_{1}$ & $91-117$ & 10YR & 5.00 & 6.00 & & $0.01 \mathrm{Y}$ & 6.75 & 5.88 & \\
\hline $\mathrm{Bw}_{2}$ & $117-152$ & 10YR & 5.00 & 6.00 & & $0.05 \mathrm{Y}$ & 7.01 & 6.00 & \\
\hline \multicolumn{10}{|c|}{ P2- Typic Paleudult (Yellow Argisol eutrophic typical, clay texture, A anthropic) } \\
\hline $\mathrm{Ap}_{1}$ & $0-15$ & 10YR & 2.00 & 1.00 & & 9.82YR & 4.09 & 3.69 & \\
\hline $\mathrm{Ap}_{2}$ & $19-30$ & 10YR & 2.00 & 2.00 & & 9.82YR & 4.66 & 4.06 & \\
\hline $\mathrm{AB}$ & $30-48$ & 10YR & 3.00 & 3.00 & & 9.79YR & 5.40 & 5.03 & \\
\hline $\mathrm{Bt}_{1}$ & $48-66$ & 10YR & 4.00 & 4.00 & & 9.28YR & 5.67 & 6.01 & \\
\hline $\mathrm{Bt}_{2}$ & $66-100$ & 10YR & 5.00 & 6.00 & & 9.09YR & 5.88 & 6.33 & \\
\hline $\mathrm{Bt}_{3}$ & $100-130$ & 10YR & 5.00 & 8.00 & & 9.24YR & 5.88 & 6.52 & \\
\hline \multicolumn{10}{|c|}{ P3- Typic Paleudult (Yellow Argisol dystrophic typical, silty texture, A anthropic) } \\
\hline $\mathrm{Ap}_{1}$ & $0-21$ & 10YR & 2.00 & 1.00 & & 9.54YR & 3.46 & 3.66 & \\
\hline $\mathrm{Ap}_{2}$ & $21-36$ & 10YR & 2.00 & 2.00 & & 9.78YR & 3.94 & 3.80 & \\
\hline $\mathrm{AB}$ & $36-58$ & 10YR & 3.00 & 3.00 & & 9.85YR & 4.47 & 4.27 & \\
\hline $\mathrm{Bt}_{1}$ & $58-91$ & 10YR & 4.00 & 4.00 & & 9.95YR & 5.73 & 5.54 & \\
\hline $\mathrm{BCr}$ & $91-120+$ & 10YR & 5.00 & 8.00 & & $0.03 Y$ & 6.08 & 6.02 & \\
\hline \multicolumn{10}{|c|}{ P4- Typic Paleudult (Yellow Argisol dystrophic typical, clay texture, A anthropic) } \\
\hline Ap & $0-21$ & 10YR & 2.00 & 2.00 & & $0.77 \mathrm{Y}$ & 4.70 & 3.54 & \\
\hline$A B$ & $21-36$ & $10 Y R$ & 4.00 & 3.00 & & $0.75 Y$ & 6.18 & 5.05 & \\
\hline $\mathrm{Bt}_{1}$ & $36-58$ & $10 Y R$ & 5.00 & 6.00 & & $0.41 Y$ & 6.60 & 5.86 & \\
\hline $\mathrm{Bt}_{2}$ & $58-91$ & 10YR & 5.00 & 8.00 & & $0.18 Y$ & 6.77 & 6.38 & \\
\hline $\mathrm{Bt}_{3}$ & $91-120+$ & 10YR & 5.00 & 8.00 & & $0.05 \mathrm{Y}$ & 6.73 & 6.45 & \\
\hline \multicolumn{10}{|c|}{ P5- Typic Udipsamments (Regolithic Neosol dystrophic typical, sandy medium texture, A anthropic) } \\
\hline $\mathrm{Ap}_{1}$ & $0-18$ & 10YR & 2.00 & 1.00 & & $0.17 Y$ & 3.73 & 3.13 & \\
\hline $\mathrm{Ap}_{2}$ & $18-31$ & 10YR & 2.00 & 2.00 & & $0.28 \mathrm{Y}$ & 3.89 & 3.07 & \\
\hline AC & $31-49$ & 10YR & 4.00 & 3.00 & & $0.27 \mathrm{Y}$ & 4.17 & 3.66 & \\
\hline $\mathrm{C}_{1}$ & $49-70$ & 10YR & 5.00 & 4.00 & & $0.02 \mathrm{Y}$ & 5.60 & 4.99 & \\
\hline $\mathrm{C}_{2}$ & $70-90$ & 10YR & 5.00 & 6.00 & & 9.64YR & 5.70 & 6.03 & \\
\hline$C_{3}$ & $90-116$ & 10YR & 5.00 & 8.00 & & 9.53YR & 5.77 & 6.24 & \\
\hline $\mathrm{C}_{4}$ & $116-135$ & 10YR & 5.00 & 8.00 & & 9.33YR & 5.83 & 6.62 & \\
\hline \multicolumn{10}{|c|}{ P6- Typic Paleudult (Yellow Argisol dystrophic typical, clay texture, A anthropic) } \\
\hline $\mathrm{Ap}_{1}$ & $0-5$ & $10 \mathrm{YR}$ & 2.00 & 2.00 & & $0.06 \mathrm{Y}$ & 4.60 & 4.15 & \\
\hline $\mathrm{AB}$ & $19-30$ & 10YR & 3.00 & 4.00 & & 9.95YR & 5.19 & 4.96 & \\
\hline $\mathrm{Bt}_{1}$ & $30-48$ & 10YR & 4.00 & 4.00 & & 9.59YR & 6.12 & 6.17 & \\
\hline $\mathrm{Bt}_{2}$ & $48-66$ & 10YR & 5.00 & 6.00 & & 9.39YR & 6.28 & 6.74 & \\
\hline $\mathrm{Bt}_{3}$ & $66-100$ & 10YR & 6.00 & 6.00 & & 9.76YR & 6.75 & 6.49 & \\
\hline $\mathrm{Bt}_{4}$ & $100-130$ & 10YR & 6.00 & 8.00 & & 9.01YR & 6.05 & 5.50 & \\
\hline
\end{tabular}


The ratio $\mathrm{Gt} /(\mathrm{Gt}+\mathrm{Hm})$ in the DAE profiles values above $50 \%$ in the surface and subsurface layers for all profiles, indicating a greater presence of goethite. This statement is reinforced by Gt and Hm contents, where in all profiles; there is a predominance of Gt (Table 5). Gt prevalence within these soils can be explained by OM accumulation along profiles as regards of the anthropogenic formation. As according to Schwertmann and Taylor (1989), organic matter favors Gt formation to the detriment of $\mathrm{Hm}$, working on iron complexation and ferrihydrite inhibition, which is a Hm precursor (Curi and Franzmeier, 1984).

\subsection{Color measurement and determination of hematite and goethite by $X R D$ and DRS}

Colors observed by DRS and matched to a Munsell Color Chart, in which are determined hue (light wavelength), value (brightness or tonality) and chroma (color intensity or pureness in relation to gray) presented differences (Table 6). This is because Munsell Color Chart identification is based on visual perception; therefore, being subjective, in which the factors of greatest effect are non-objective (Melville and Atkinson, 1985; Post et al., 1993). On the other hand, color determination by DRS is qualitative, that is, has greater precision due to its controlled conditions (Botelho et al., 2006).

The hue identified by Munsell Chart presented 10YR color notation in all profiles, while DRS hue presented values close to those indicated by the Munsell Chart in profiles P1, P2, P3 and P6; and in P4 and P5, it presented measures ranging from 9.64YR to 0.02Y (Table 6). Organic matter promotes dark colors on surface horizons and some subsurface horizons (illuvial). Red, yellow and dark colors are attributed to the presence of iron oxides, while grayish colors are related to reduction and removal of iron oxides in hydromorphic conditions (Barrón and Torrent, 1986; Azevedo and Dalmolin, 2004; Botelho et al., 2006).

Both the Munsell Chart and the DRS values were lower in the surface layers, in which the anthropogenic horizons are located, and increased with depth. This trend is related to organic matter high content in anthropogenic horizons (Botelho et al., 2006). The chroma presented the highest variation in Munsell and DRS (Table 6) what may be related to visual toughness to evaluate chroma since shades of gray are not well discerned by eyes.

There is a clear difference between Munsell Color Chart and DRS results about hue, value and chroma. These results show the importance of more precise quantitative techniques, such as DRS, for interpreting soil color measurement, given its importance in Brazilian Soil Science. Barrón and Torrent (1986) reported that DRS is useful not only for color identification but also for quantification of iron oxide amounts, in particular $\mathrm{Hm}$ and $\mathrm{Gt}$, once they are highly correlated with soil coloring.

With the purpose of measure DRS technique accuracy in quantifying iron oxides indirectly, the levels of $\mathrm{Hm}$ and $\mathrm{Gt}$, estimated by this methodology, were related to levels of these minerals determined by x-ray diffraction (XRD) (Fig. 2). The results show that there was a positive relation between the methods for $\mathrm{Hm}(\mathrm{r}=0.78$; $\mathrm{p}<0.01)$ and $\mathrm{Gt}$ $(\mathrm{r}=0.98 ; \mathrm{p}<0.01)$, indicating that the DRS can be used in quantifying these iron oxides indirectly also in ADEs. The high $\mathrm{R}^{2}$ in Gt can be related to the stronger presence of this mineral in DAE profiles, evidenced in Table 6.

The results above indicate that the DRS technique is a promising alternative to be used for indirect determination of soil attributes. This can be stated, since $\mathrm{Hm}$ and Gt are covariate minerals of soil processes, and therefore, are an auxiliary tool in the characterization of different environments in the Amazonas region.

\subsection{Multivariate analysis $-P C A$}

In order to evaluate the interaction of physical, chemical and mineralogical attributes with the anthropogenic profiles was used to principal component analysis (PCA) (Fig. 3). The PCA has confirmed the results presented for the characterization of profiles (Tables 2, 3, 4 e 5). The first group was formed by P2 and P6, showing strong relationship with clay fraction and soil mineralogy, represented mainly by $\mathrm{Hm}, \mathrm{Gt}$ and $\mathrm{Fe}_{\mathrm{d}}$. The second group was formed by P1, P3 and P4 and is linked to variables that indicate soil weathering. These profiles present soils with higher degree of development and are related to attributes and $\mathrm{Ki}, \mathrm{Kr}, \mathrm{H}+\mathrm{Al}, \mathrm{m} \%$ and $\mathrm{SiO}_{2}$, which are attributes that characterize the soil evolution. This result agrees with the work of Santos et al. (2013) that found high degree of weathering in the Archeological Dark Earth profiles.

Finally, the third group was formed by P5, related with the thicker fractions of the soil, prevalent in this profile (fine sand, gravel and DF). This result is justified mainly by the position of the profile in the relief, slope (Table 1). Campos et al. (2011), doing a study of characterization and classification of Archeological Dark Earth in the region of the Middle Madeira River, Amazonas (Brazil) also found dominance of the sand fraction, influenced mainly by the position in the relief.

In the layer of sub-surface horizons (diagnostic horizons) remained the same distribution of variables with the formation of three groups linked to the same profiles, indicating that the anthropogenic horizon is influencing directly on soil attributes even with increasing depth (Fig. 3).

\section{Conclusions}

Hematite and goethite minerals determined by $\mathrm{x}$-ray diffraction and diffuse reflectance spectroscopy, besides not presenting significant variations between the soils, have similar characteristics to non-anthropogenic Brazilian soils.

The color as measured by diffuse reflectance spectroscopy proved efficient to indicate variations between the studied Archeological Dark Earth, proving to be an innovative technique, efficient and promising for indirect quantification of soil attributes in a simple and low cost manner.

The results show that iron oxides are sensitive indicators of pedoenvironmental and pedogenic processes of Archeological Dark Earth.

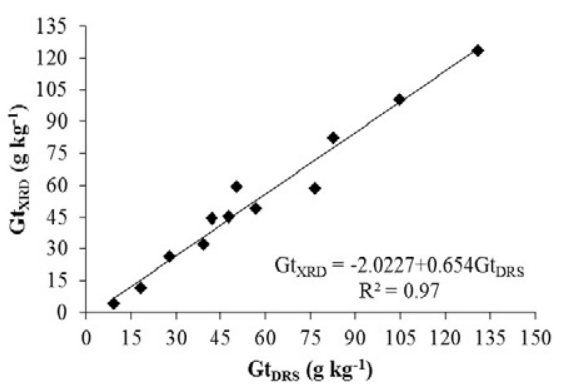

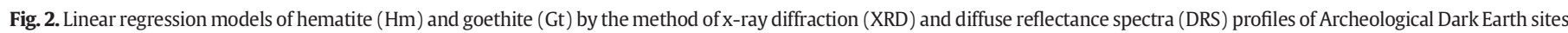
in Apuí region, southern of Amazonas state, Brazil. 

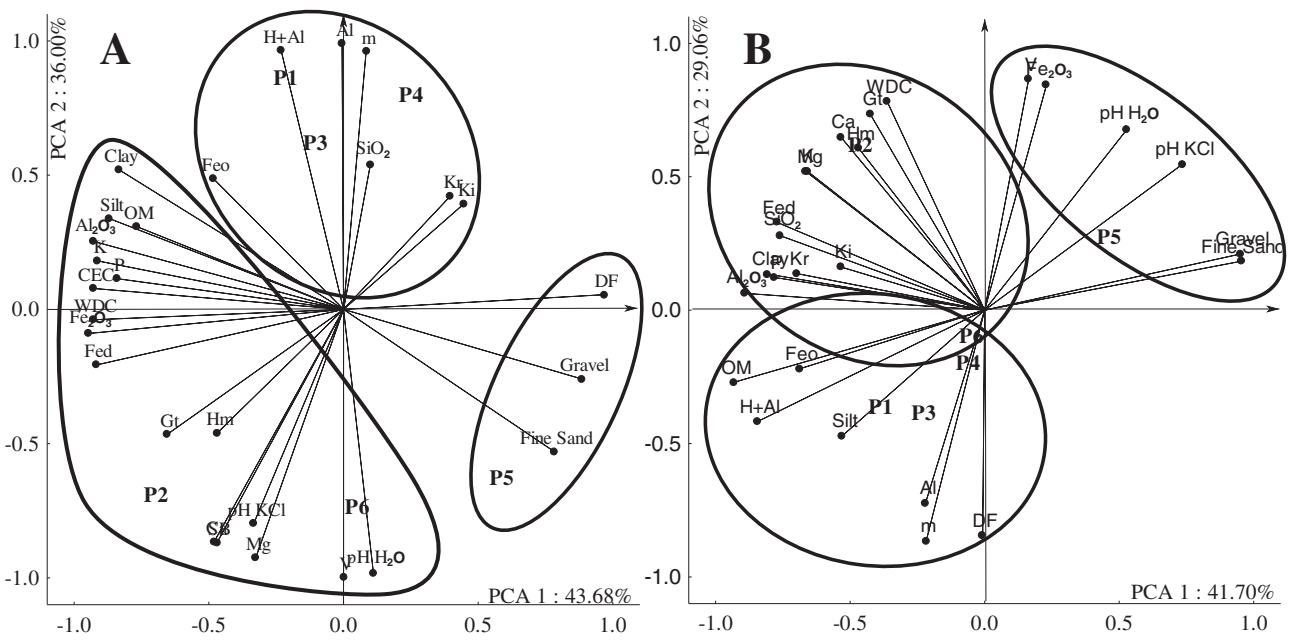

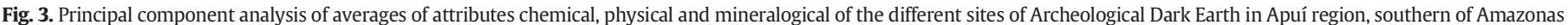
state, Brazil. A = surface horizons; B = subsurface horizons.

Therefore, knowing that Brazilian taxonomic system is in process of construction, the color can continue being a diagnostic attribute relevant to the classification of Archeological Dark Earth, when determined by diffuse reflectance spectroscopy.

\section{Acknowledgments}

We are grateful to the Fundacão de Amparo à Pesquisa do Estado do Amazonas (FAPEAM) for the granting of master's scholarships to the first and fourth authors, to Fundacão de Amparo à Pesquisa do Estado de São Paulo (FAPESP) for research support to our study, and Conselho Nacional de Desenvolvimento Científico e Tecnológico (CNPq) for the research scholarships of productivity to the second and third authors.

\section{References}

Azevedo, A.C., Dalmolin, R.S.D., 2004. Solos e ambiente: uma introdução. Palotti, Santa Maria (100 pp.).

Bahia, A.S.R.S., Marques Jr., J., Panosso, A.R., Camargo, L.A., Siqueira, D.S., La Scala, N., 2014. Iron oxides as proxies for characterizing anisotropy in soil $\mathrm{CO}_{2}$ emission in sugarcane areas under green harvest. Agric. Ecosyst. Environ. 192, 152-162.

Barrón, V., Torrent, J., 1986. Use of the Kubelka-Munk theory to study the influence of iron oxides on soil colour. J. Soil Sci. 37, 499-510.

Barrón, V., Mello, J.W.V., Torrent, J., 2000. Caracterização de óxidos de ferro em solos por espectroscopia de reflectância difusa. In: Novais, R.F., Alvarez, V., V. H., Schaefer, C.E.G.R. (Eds.), Tópicos em ciência do solo 1. Sociedade Brasileira de Ciência do solo, Viçosa, pp. 139-162.

Barros, K.R.M., Lima, H.V., Canellas, L.P., Kern, D.C., 2012. Fracionamento químico da matéria orgânica e caracterização física de Terra Preta de Índio. Rev. Ciênc. Agrár. 55, 44-51.

Botelho, M.R., Dalmolin, R.S.D., Pedron, F.A., Azevedo, A.C., Rodrigues, R.B., Miguel, P., 2006. Medida da cor em solos do Rio Grande do Sul com a carta de Munsell e por colorimetria. 36. Cienc. Rural, pp. 1179-1185.

Brown, D.J., Shepherd, K.D., Walsh, M.G., Mays, M.D., Reinsch, T.G., 2006. Global soil characterization with VNIR diffuse reflectance spectroscopy. Geoderma 132, 273-290.

Camargo, O.A., Moniz, A.C., Jorge, J.A., Valadares, J.M.A.S., 1986. Métodos de análise química, mineralógica e física de solos do IAC. Instituto Agronômico de Campinas, Campinas (94 pp. (Boletim Técnico, 106)).

Campos, R.C., Demattê, J.A.M., 2004. Cor do solo: uma abordagem da forma convencional de obtenção em oposição a automatização do método para fins de classificação de solos. Rev. Bras. Ciênc. Solo 28, 853-863.

Campos, M.C.C., Ribeiro, M.R., Souza Júnior, V.S., Ribeiro Filho, M.R., Souza, R.V.C.C. Almeida, M.C., 2011. Caracterização e Classificação de Terras Pretas Arqueológicas na região do Médio Rio Madeira. Bragantia 70, 18-27.

Campos, M.C.C., Santos, L.A.C., Silva, D.M.P., Mantovaneli, B.C., Soares, M.D.R., 2012. Caracterização física e química de terras pretas arqueológicas e de solos não antropogênicos na região de Manicoré. 6. Revista Agro@mbiente, Amazonas, pp. 102-109.

Centro de Pesquisa de Recursos Minerais - CPRM, 2001. Hidroclimatologia, geologia, recursos minerais, geomorfologia e unidades de paisagens. Manaus (93 pp. (Relatório Técnico)).

Centro de Pesquisa de Recursos Minerais - CPRM, 2010. Geodiversidade do estado do Amazonas. Programa geologia do Brasil levantamento da geodiversidade, Manaus (275 pp.).
Cornell, R.M., Schwertmann, U., 1996. The iron oxides: structure, properties, reactions, occurrence and uses. VHC, Weinheim (573 pp.).

Cunha, T.J.F. Madari, B.E., Benites, V.M., Canelas, L.P., Novotny, E.H., Moutta, R.O. Trompowsky, P., Santos, G.A., 2007. Fracionamento químico da matéria orgânica e características de ácidos húmicos de solos com horizonte A antrópico da Amazônia (Terra Preta). Acta Amazon. 37, 91-98.

Cunha, T.J.F., Madari, B.E., Canellas, L.P., Ribeiro, L.P., Benites, V.M., Santos, G.A., 2009. Soil organic matter and fertility of anthropogenic dark earths (Terra Preta de Índio) in the Brazilian Amazon basin. Rev. Bras. Ciênc. Solo 33, 85-93.

Curi, N., Franzmeier, D.P., 1984. Toposequence of Oxisols from the central plateau of Brazil. Soil Sci. Soc. Am. J. 48, 341-346.

Dick, D.P., 1986. Caracterização de óxidos de ferro e adsorção de fósforo na fração argila de horizontes B latossólicos. Universidade Federal do Rio Grande do Sul, Porto Alegre (196 pp. (Dissertação de Mestrado)).

Empresa Brasileira de Pesquisa Agropecuária - EMBRAPA, 1979. Serviço Nacional de Levantamento e Conservação de Solos. Manual de métodos análise de solo. Rio de janeiro (247 pp.).

Empresa Brasileira de Pesquisa Agropecuária - EMBRAPA, 1997. Centro Nacional de Pesquisa de Solos. Manual de métodos de análise de solo. Rio de Janeiro (212 pp.).

Empresa Brasileira de Pesquisa Agropecuária - EMBRAPA, 2013. Sistema brasileiro de classificação de solos. 3. ed. Embrapa Solos, Brasília (353 pp.)

Falcão, N.P.S., Borges, L.F., 2006. Efeito da fertilidade de terra preta de índio da Amazônia Central no estado nutricional e na produtividade do mamão hawaí (Carica papaya L.). Acta Amazon. 36, 401-406.

Fitzpatrick, R.W., Schwertmann, U., 1982. Al-Substituted goethite indicator of pedogenic and other weathering environments in South Africa. Geoderma 27, 335-347.

German, L.A., 2003. Historical contingencies in the coevolution of environment and livelihood: contributions to the debate on Amazonian Black Earth. Geoderma 111, 307-331.

Glaser, B., Balashov, E., Haumaier, L., Guggenberger, G., Zech, W., 2000. Black carbon in density fractions of anthropogenic soils of the Brazilian Amazon region. Geoderma 31, 669-678.

Jacomine, P.K.T., 2005. Origem e evolução dos conceitos e definições de atributos, horizontes diagnósticos e das classes de solos do sistema Brasileiro de classificação de solos (siBcs). In: Vidal-Torrado, P., Alleoni, L.R.F., Cooper, M., Silva, A.P., Cardoso, E.J. (Eds.), Tópicos em ciência do solo 4. Sociedade Brasileira de Ciência do Solo, Viçosa, MG, pp. 193-231.

Kämpf, N., Curi, N., 2000. Óxidos de ferro: indicadores de ambientes pedogênicos e geoquímicos. In: Novais, R.F., Alvarez, V.H., Schaefer, C.E.G.R. (Eds.), Tópicos em Ciência do Solo 1. SBCS, Viçosa, pp. 107-138.

Kämpf, N., Schwertmann, U., 1982. Goethite and hematite in a climosequence in Southern Brazil and their application in classification of kaolinitic soils. Geoderma 29, 27-39.

Kämpf, N., Schwertmann, U., 1998. Avaliação da estimativa de substituição de Fe por Al em hematitas de solos. Rev. Bras. Ciênc. Solo 22, 209-213.

Kämpf, N., Resende, M., Curi, N., 1988. Iron oxides in Brazilian oxisols. In: Beinroth, F.H. Camargo, M.N., Eswaran, H. (Eds.), International Soil Classification Workshop Classification, Characterization and Utilization of Oxisols, 8., Rio de Janeiro, pp. 71-77.

Kern, D.C., Kämpf, N., 1989. O efeito de antigos assentamentos indígenas na formação de solos com terra preta arqueológica na região de Oriximiná-PA. Rev. Bras. Ciênc. Solo 13, 219-225

Kern, D.C., D'Aquino, G., Rodrigues, T.E., Frazão, F.J.L., Sombroek, W., Neves, E.G., Myers, T.P., 2003. Distribution of antropogenic dark earths. In: Lehmann, J., Kern, D.C., Woods, W., Glaser, B., (Org.) (Eds.), Amazonian dark earths: origin, properties, management 1. Kluwer Academic Publishers, Norwell, pp. 51-76.

Kim, J.S., Sparovek, G., Longo, R.M., De Melo, W.J., Crowley, D., 2007. Bacteria diversity of terra preta and pristine forest soil from the western Amazon. Soil Biol. Biochem. 39, 684-690.

Klug, H.P., Alexande, R.L.E., 1974. X-ray diffraction procedures for polycrystalline and amorphous materials. John Wiley \& Sons, New York (966 pp.). 
Köppen, W., 1948. Climatologia: com um estúdio de los climas de la tierra. Publications. Climatology. Laboratory of Climatology, New Gersey (104 pp.),

Lehmann, J., Kern, D.C., German, L., McCann, J., Martins, G.C., Moreira, A., 2003. Soil fertility and production potential. In: Lehmann, J., Kern, D.C., Glaser, B., Woods, W.I. (Eds.), Amazonian Dark Earths: Origin, Properties, Management. Kluwer Academic Publishers, Dordrecht, The Netherlands, pp. 105-124.

Liang, B., Lehmann, J., Solomon, D., Kinyangi, J., Grossman, J., O Neill, B., Skjemstad, O., Thies, J., Luizão, F.J., Petersen, J., Neves, E.G., 2006. Black carbon increases cation exchange capacity in soils. Soil Sci. Soc. Am. J. 70, 1719-1730.

Lima, H.N., Schaefer, C.E.R., Mello, J.W.V., Gilkes, R.J., Ker, J.C., 2002. Pedogenesis and precolombian land use of terra preta anthrosols ("indian black earth") of western Amazonia. Geoderma 110, 01-17.

Macedo, M., Teixeira, W.G., 2009. Sul do Amazonas, nova fronteira agropecuária? O caso do município de Humaitá. Simpósio Brasileiro de Sensoriamento Remoto, 24, 2009, Natal. INPE, Anais... São José dos Campos, pp. 5933-5940.

Mehra, O.P., Jackson, M.L., 1960. Iron oxide from soils and clays by a dithionite - citrate system buffered with sodium bicarbonate. Clay Clay Miner. 7, 317-327.

Meirelles, H.T., Marques Júnior, J., Campos, M.C.C., Pereira, G.T., 2012. Replaces solo-paisa gem em topossequência de origem basáltica. Pesq. Agrop. Trop. 42, 129-136.

Melville, M.D., Atkinson, G., 1985. Soil color: its measurement and its designation in models of uniform color space. J. Soil Sci. 36, 495-512.

Moreira, A., 2006. Fertilidade, matéria orgânica e substâncias húmicas em solos antropogênicos da Amazônia Ocidental. Bragantia 66, 307-315.

Navarrete, A.A., Cannavan, F.S., Taketani, R.G., Tsai, S.M., 2010. A molecular survey of the diversity of microbial communities in different Amazonian agricultural model systems. Diversity 2, 787-809.

Norrish, K., Taylor, R.M., 1961. The isomorphous replacement of iron by aluminium in soil goethites. J. Soil Sci. 12, 294-306.

Post, D.F., Bryant, R.B., Batchily, A.K., Huete, A.R., Levine, S.J., Mays, M.D., Escadafal, R., 1993. Correlations between field and laboratory measurements of soil color. In: Bigham, J.M., Ciolkosz, E.J. (Eds.), Soil color. S. Sci. Soc. Am, Madison, pp. 35-49 (Special Publication, 31).

Resende, M., 1976. Mineralogy, chemistry, morphology and geomorphology of some soils of Central Plateau of Brazil. Purdue University, Purdue (237 pp. (Thesis PhD)).

Resende, M., Santana, D.P., 1988. Uso das relações Ki e Kr na estimativa da mineralogia para classificação de Latossolos. Reunião de classificação, correlação de solos e interpretação da aptidão agrícola, 3, Rio de Janeiro, 1988. Embrapa-SNLCS/SBCS, Anais ... Rio de Janeiro, pp. 225-232.

Resende, M., Curi, N., Rezende, S.B., Correa, G.F., 2007. Pedologia: Base para distinção de ambientes. 5. ed. rev. UFLA, Lavras-MG (322 p.il).

Resende, M., Curi, N., Ker, J.C., Rezende, S.B., 2011. Mineralogia de solos brasileiros: Interpretação e Aplicação. 2ed. UFLA, Lavras (206 pp.).

Rezende, S.B., 1980. Geomorphology, mineralogy and genesis of four soils on gneiss in Southe astern Brazil. Purdue University, West Lafayette (143 pp. (Tese de Doutorado)).

Rodrigues, T.E., 1996. Solos da Amazônia. In: Alvarez, V.V.H., Fontes, L.E.F., Fontes, M.P.F. (Eds.), O solo nos grandes domínios morfoclimáticos do Brasil e o desenvolvimento sustentado. Sociedade Brasileira de Ciência do Solo, Universidade Federal de Viçosa, Viçosa, pp. 19-60.
Santos, R.D., Lemos, R.C., Santos, H.G., Anjos, L.H., 2005. Manual de descrição e coleta de solos no campo. 5. ed. Sociedade Brasileira de Ciência do Solo, Viçosa (100pp.).

Santos, L.A.C., Campos, M.C.C., Aquino, R.E., Bergamin, A.C., Silva, D.M.P., Marques Junior, J., Franca, A.B.C., 2013. Caracterização e gênese de terras pretas arqueológicas no sul do Estado do Amazonas. Rev. Bras. Ciênc. Solo 37, 825-836.

Schulze, D.G., 1984. The influence of aluminium on iron oxides VIII. Unit-cel dimension of Al-substituted of goethites and estimation of Al from them. Clay Clay Miner. 32 36-44.

Schwertmann, U., Kämpf, N., 1985. Properties of goethite and hematite in kaolinitic soils of Southern and Central Brazil. Soil Sci. 139, 344-350.

Schwertmann, U., Taylor, R.M., 1989. Iron oxides. In: Dixon, J.B., Weed, S.B. (Eds.) Minerals in soil environments, 2.ed. SSSA, Madison, pp. 379-438 (Book Series, 1).

Schwertmann, U., Fitzpatrick, R.W., Taylor, R.M., Lewis, D.G., 1979. The influence of aluminium on iron oxides. Part II: preparation and properties of Al-substituted hematites. Clay Clay Miner. 27, 105-112.

Secretaria de estado do meio ambiente e desenvolvimento sustentável - SDS, 2004 Relatório técnico síntese dos diagnósticos: Área estadual sul de Apuí e Manicoré. Manaus (20 pp.).

Silva Neto, L.F., Inda Junior, A.V., Bayer, C., Dick, D.P., Tonin, A.T., 2008. Óxidos de ferro em Latossolos tropical e subtropical brasileiros em plantio direto. Rev. Bras. Ciênc. Solo 32, 1873-1881.

Silva, F.W.R., Lima, H.N., Teixeira, W.G., Motta, M.B., Santana, R.M., 2011. Caracterização química e mineralogia de solos antrópicos (terras pretas de índio) na Amazônia Central. Rev. Bras. Ciênc. Solo 35, 673-681.

Silva, A.K.T., GuimarãeS, J.T.F., Lemos, V.P., Costa, M.L., Kern, D.C., 2012. Mineralogia e geoquímica de perfis de solo com Terra Preta Arqueológica de Bom Jesus do Tocantins, sudeste da Amazônia. Acta Amazon. 42, 477-490.

SoilSurvey Staff, 1999. Soil taxonomy: a basic system of soil classification for making and interpreting soil surveys. 2 ed. USDA-NRCS, Washington, DC, USA.

STATSOFT, Inc., 2004. STATISTICA (data analysis software system) version 7.

Teixeira, W.G., Martins, G.C., 2003. Soil physical characterization. In: Lehmann, J., Kern, D.C., Glaser, B., Woods, W.I. (Eds.), Amazonian dark earths; origin, properties and management. Kluwer Academic Publishers, Dordrecht, pp. 271-286.

Torrent, J., Barron, V., 1993. Laboratory measurements of soil color: theory and practice. In: Bigham, J.M., Ciolkosz, E.J. (Eds.), Soil Color. Soil Science Society of America, pp. 21-33 (Special Publication).

van Raij, B., Quaggio, J.A., Cantarella, H., Ferreira, M.E., Lopes, A.S., Bataglia, O.C., 1987 Análise química de solo para fins de fertilidade. Fund. Cargill, Campinas (170 pp.).

Viscarra rossel, R.A., Webster, R., 2011. Discrimination of Australian soil horizons and classes from their visible-near infrared spectra. Eur. J. Soil Sci. 62, 637-647.

Viscarra Rossel, R.A., Walvoort, D.J.J., McBratney, A.B., Janik, L.J., Skjemstad, J.O., 2006. Visible, near infrared, mid infrared or combined diffuse reflectance spectroscopy for simultaneous assessment of various soil properties. Geoderma 131, 59-75.

Yeomans, J.C., Bremner, J.M., 1988. A rapid and precise method for routine determination of organic carbon in soil. Commun. Soil Sci. Plant Anal. 19, 1467-1476. 